\title{
Tamoxifen stimulates arachidonic acid release from rat liver cells by an estrogen receptor-independent, non-genomic mechanism
} Lawrence Levine*

\author{
Address: Department of Biochemistry, Brandeis University, Waltham, MA 02454, U.S.A \\ Email: Lawrence Levine* - llevine@brandeis.edu \\ * Corresponding author
}

Published: 19 September 2003

BMC Cancer 2003, 3:24
Received: 09 June 2003

Accepted: 19 September 2003

This article is available from: http://www.biomedcentral.com/I47/-2407/3/24

(C) 2003 Levine; licensee BioMed Central Ltd. This is an Open Access article: verbatim copying and redistribution of this article are permitted in all media for any purpose, provided this notice is preserved along with the article's original URL.

\begin{abstract}
Background: Tamoxifen is widely prescribed for the treatment of breast cancer. Its success has been attributed to the modulation of the estrogen receptor. I have previously proposed that the release of arachidonic acid from cells may also mediate cancer prevention.
\end{abstract}

Methods: Rat liver cells were radiolabelled with arachidonic acid. The release of $\left[{ }^{3} \mathrm{H}\right]$ arachidonic acid after various times of incubation of the cells with tamoxifen was measured.

Results: Tamoxifen, at micromolar concentrations, stimulates arachidonic acid release. The stimulation is rapid and is not affected by pre-incubation of the cells with actinomycin or the estrogen antagonist $\mathrm{ICl}-182,780$.

Conclusions: The stimulation of AA release by tamoxifen is not mediated by estrogen receptor occupancy and is non-genomic.

\section{Background}

Clinically, breast cancer chemoprevention by tamoxifen has been attributed to its antiestrogenic properties [1-3]. Tamoxifen also has been shown to prevent cancer in animal studies by a mechanism of action that is based, in part, on its antiestrogenic activity $[1,4]$. However, at $\mu \mathrm{M}$ levels, tamoxifen releases arachidonic acid (AA) from rat liver cells [5]. This ability to release AA, a molecule whose multiple bioactivities [6] include induction of apoptosis [7], suggests a mechanism for cancer prevention that does not require metabolism by cyclooxygenase [8]. I suggest that AA release from cells may be a part of a mechanism by which tamoxifen prevents cancer.

Tamoxifen has several biological effects, some of which may be beneficial. It also has unfavorable effects, especially its estrogenic activity on the uterus $[1,2]$. One of the many activities associated with perturbation of the plasma membrane and/or release of AA may mediate some of these biological effects.

\section{Materials and Methods}

The C-9 rat liver cell line was purchased from the American Type Culture Collection (Manassas, VA, USA). The cells were maintained in Eagle's minimum essential medium (MEM) supplemented with 10\% fetal bovine serum. $\left[{ }^{3} \mathrm{H}\right]$ AA $(91.8 \mathrm{Ci} / \mathrm{mmol})$ was obtained from NEN Life Science Products, Inc. (Boston, MA, USA). ICI182,780 was purchased from Tocris Cookson, Inc. (Ballwin, MO, USA). All other reagents were from Sigma Chemical Co. (St. Louis, MO, USA).

Two days prior to experiments, the rat liver cells were treated with $0.25 \%$ trypsin-EDTA and, after addition of minimal essential media (MEM) containing $10 \%$ fetal calf serum, the floating cells were seeded onto $35 \mathrm{~mm}$ culture 
dishes. The plating densities varied from 0.1 to $0.5 \times 10^{5}$ cells/35 mm dish. The freshly seeded cultures were incubated for 24-h to allow for cell attachment. After decantation of MEM containing the fetal bovine serum, $1.0 \mathrm{ml}$ fresh MEM containing 10\% fetal bovine serum and $\left[{ }^{3} \mathrm{H}\right]$ AA $(0.2 \mu \mathrm{Ci} / \mathrm{ml})$ were added and the cells incubated for another 24-h. The cells were washed 4 times with MEM and incubated for various periods of time with $1.0 \mathrm{ml}$ of MEM containing $1.0 \mathrm{mg} \mathrm{BSA} / \mathrm{ml}$ and different concentrations of each compound. The culture fluids were then decanted, centrifuged at $2000 \times \mathrm{g}$ for $10 \mathrm{~min}$, and $200 \mu \mathrm{l}$ of the supernate counted for radioactivity. Radioactivity recovered in the washes before the 6-h incubation was compared to input radioactivity to calculate the \% radioactivity incorporated into the cells [9]. For $\mathrm{PGI}_{2}$ production, $1.0 \mathrm{ml}$ of MEM supplemented with $10 \%$ fetal bovine serum, void of [ $\left.{ }^{3} \mathrm{H}\right] \mathrm{AA}$, was added after the first $24-\mathrm{h}$ incubation. The cells were incubated for another 24-h, washed three times with MEM, then incubated with lactacystin plus TPA and the compounds in MEM/BSA for various periods of time. The culture fluids were decanted and analyzed for 6-keto-PGF ${ }_{1 \alpha^{\prime}}$ the stable hydrolytic product of $\mathrm{PGI}_{2}$, by radioimmunoassay [10].

The $\left[{ }^{3} \mathrm{H}\right]$ AA release is presented as a percentage of the radioactivity incorporated by the cells. Except for the timecourse experiments which used duplicate dishes. (Fig. 2), three to six culture dishes were used for each experimental point. The data are expressed as mean values \pm SEM (number of dishes). The data were evaluated statistically by the unpaired Student's t-test. A $P$ value $<0.05$ was considered significant.

\section{Results}

The release of AA from rat liver cells after a 6-h incubation with tamoxifen is dependent on the concentration of the drug (Fig. 1). Even at $8 \mu \mathrm{M}$, the stimulation of AA release is significant statistically. Tamoxifen $(8 \mu \mathrm{M})$ also stimulates significantly AA release from rat glial cells (data not shown). After $30 \mathrm{~min}$. incubation with $12 \mu \mathrm{M}$ tamoxifen, AA release from rat liver cells is stimulated (Fig. 2). Even after a $5 \mathrm{~min}$ incubation, the AA release by $16 \mu \mathrm{M}$ tamoxifen is stimulated significantly, $1.4 \pm 0.06$ (7) vs 1.6 $\pm 0.06(7) \%$ released in MEM/BSA and in the MEM/BSA containing the $16 \mu \mathrm{M}$ tamoxifen respectively $(P<0.02)$. Tamoxifen $(16 \mu \mathrm{M})$ also stimulates prostacyclin production. After a 6 -h incubation, the stimulation of 6 -keto$\mathrm{PGF}_{1 \propto}$ production by $16 \mu \mathrm{M}$ tamoxifen was $3.1 \pm 0.18$ fold when tested with cells ranging from the $19^{\text {th }}$ to the $50^{\text {th }}$ passage. The AA release by $8 \mu \mathrm{M}$ tamoxifen after a 6 -h incubation is not affected by pre-incubation of the cells for 2-h with $1 \mu \mathrm{M}$ actinomycin (Fig. 3). Under these conditions, AA release and prostaglandin production induced by treatment of cells with lactacystin plus 12-0-tetradecanoyl-13-acetate or 15 -deoxy- $\Delta^{12,14}-\mathrm{PGJ}_{2}$ are inhibited

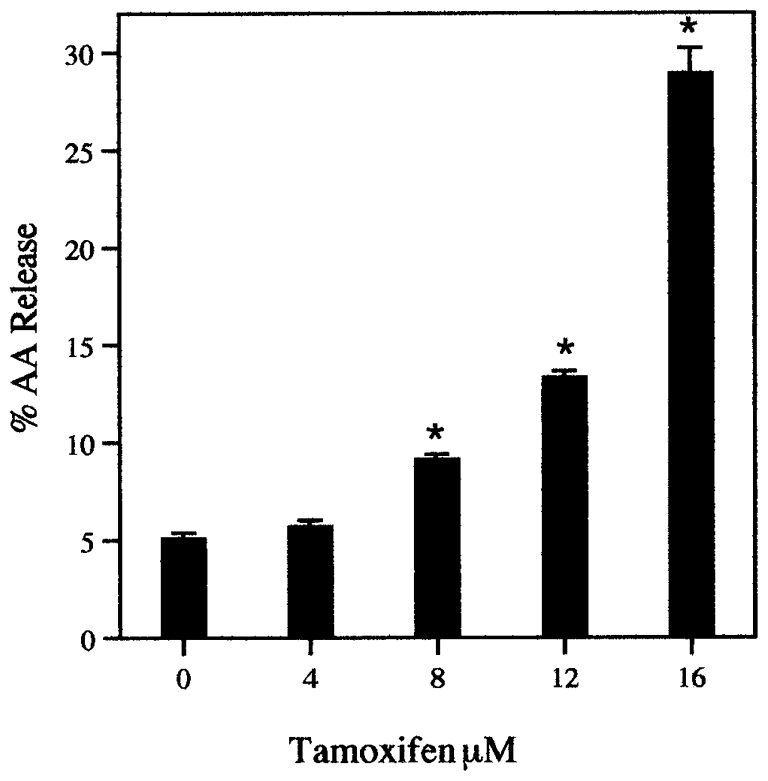

\section{Figure I}

The dependence of AA release on tamoxifen concentration. The cells were incubated for 6-h. The analyses were performed with triplicate dishes. Each bar gives the mean value and the brackets give the SEM. * = statistically different vs control. These data are representative of several independent experiments with the same results.

[11]. Pre-incubation of the cells with the estrogen antagonist ICI-182,780 $(50 \mu \mathrm{M})$ [12]for 2-h does not significantly affect the stimulation of AA release by $16 \mu \mathrm{M}$ tamoxifen (Fig. 4). ICI-182,780 (50 $\mu \mathrm{M})$, however, did affect AA release stimulated by $17 \beta$-estradiol, 22(R)cholesterol, indomethacin, all-trans-retinoic acid and the tyrosine analog of thiazolidinedione, GW7845 [11].

\section{Discussion}

Tamoxifen, in addition to its actions mediated by the estrogen receptor (ER), inhibits protein kinase C [13] and induces apoptosis in normal human mammary epithelial cells [14]. Submicromolar concentrations of tamoxifen or 4-hydroxytamoxifen induce apoptosis in ER-positive HeLa cells. However, both of these compounds, as well as estrogen, at concentrations of $10-20 \mu \mathrm{M}$, induce apoptosis in ER-negative HeLa cells [15]. The induction of apoptosis probably contributes to the effectiveness of tamoxifen in cancer prevention. AA, also induces apoptosis [8]. It has been suggested that cancer prevention by nonsteroidal antiinflammatory drugs (NSAIDs) is mediated by release of AA [8]. Several agents that prevent 


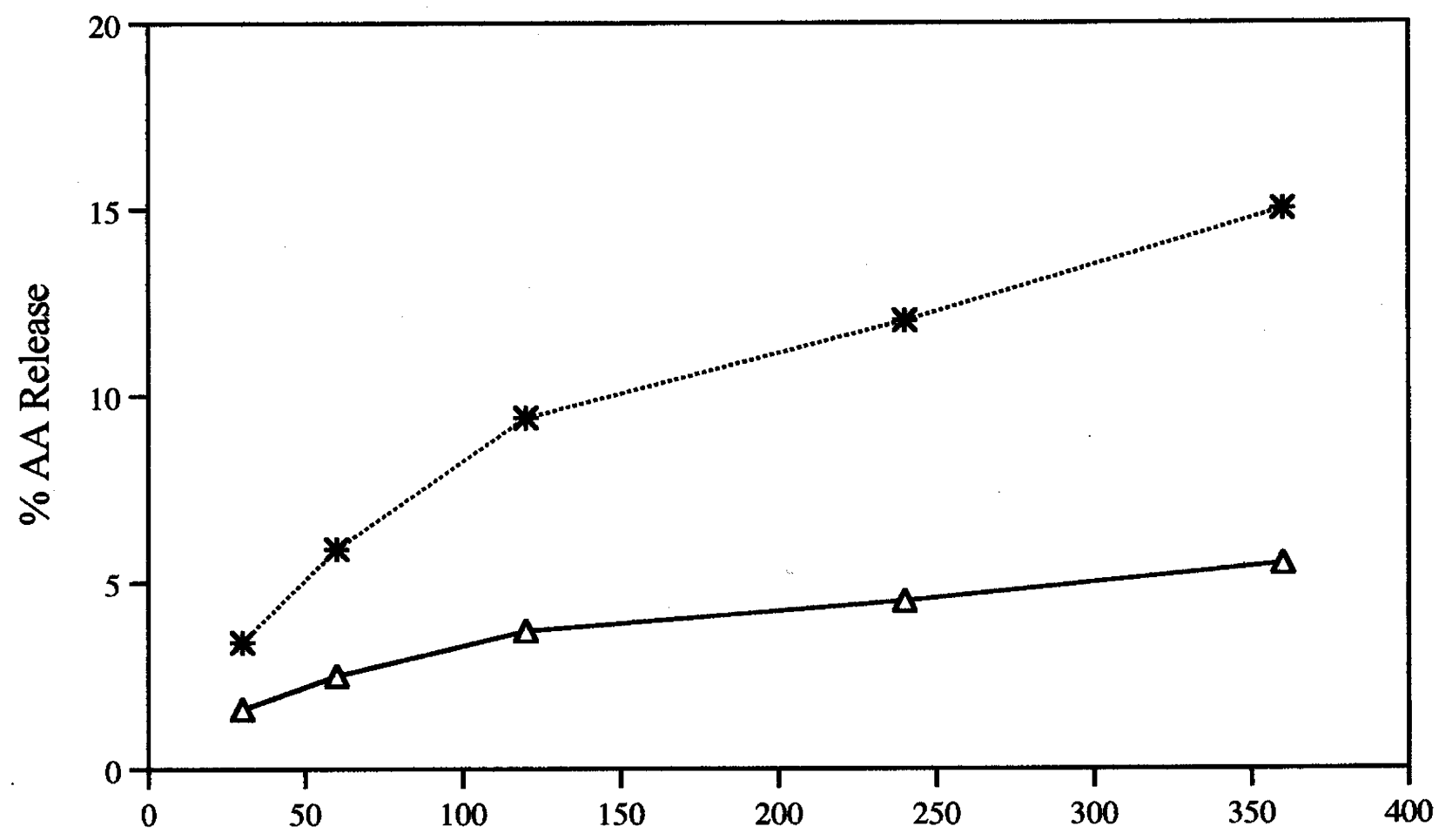

\section{Minutes}

\section{Figure 2}

Time course of release of AA during incubation with $12 \mu \mathrm{M}$ tamoxifen $\left(^{*}\right)$ and MEM/BSA control $(\triangle)$. Analyses were performed on duplicate or triplicate dishes. The average value is recorded.

cancer, including retinoids, NSAIDs, vitamin $\mathrm{D}_{3}$ and some anti-oxidants, release AA from rat liver cells [5].

The AA release by tamoxifen and other reagents studied in my laboratory occurs with $\mu \mathrm{M}$ concentrations $[5,9,11]$. These experiments were carried out in the presence of BSA $(1.0 \mathrm{mg} / \mathrm{ml})$, and therefore do not differentiate between the protein-bound and free reagent. Thus, they are likely overestimated values. Nevertheless, the possibility that general necrotic cell death may cause AA release, must be considered. Lactacystin, $(5.4 \mu \mathrm{M})$ phenylmethylsulphonyl flouride, (1 mM) carbobenzoxyleucylleucyleucinal, $(1.0 \mu \mathrm{M})$ and carbobenzoxyleucylleucylnorvalinal (0.5 $\mu \mathrm{M}$ ) were tested for rat liver cell viability by a tetrazoliumbased assay. They were not toxic at these concentrations [16]. Proteosome inhibitors are not toxic to several other cells in culture [16]. No toxicity of tamoxifen, at concentrations of 10 to $20 \mu \mathrm{M}$ for A549 human lung adenocarcinoma (ER-negative) cells was reported [17]; nor was 10 $\mu \mathrm{M}$ tamoxifen toxic when tested on rat glial cells and breast cancer MCF-7 cells [18]. Even when cell viability of three different breast cell lines (ER-positive MCF-7; ERnegative MDA-MB-239 and ER-negative BT-20 cells) was measured after incubation with $25 \mu \mathrm{M}$ tamoxifen for 24$\mathrm{h}$, the loss in viability was due to apoptosis [19] and was not the result of necrotic cell death. Concentrations of tamoxifen used in this report are comparable to those found to induce apoptosis, not necrotic cell death. The median concentration of tamoxifen and its metabolites for clinical effectiveness in the treatment of breast cancer varies from $0.8 \mu \mathrm{M}$ to $2.4 \mu \mathrm{M}$, depending on the age of the woman [20].

The stimulation of AA release by tamoxifen is non-transcriptional as indicated by the lack of inhibition by actinomycin (Fig. 3). The stimulation of AA release by tamoxifen also is not ER mediated as indicated by the lack of inhibition by the estrogen antagonist ICI-182,780 (Fig. 


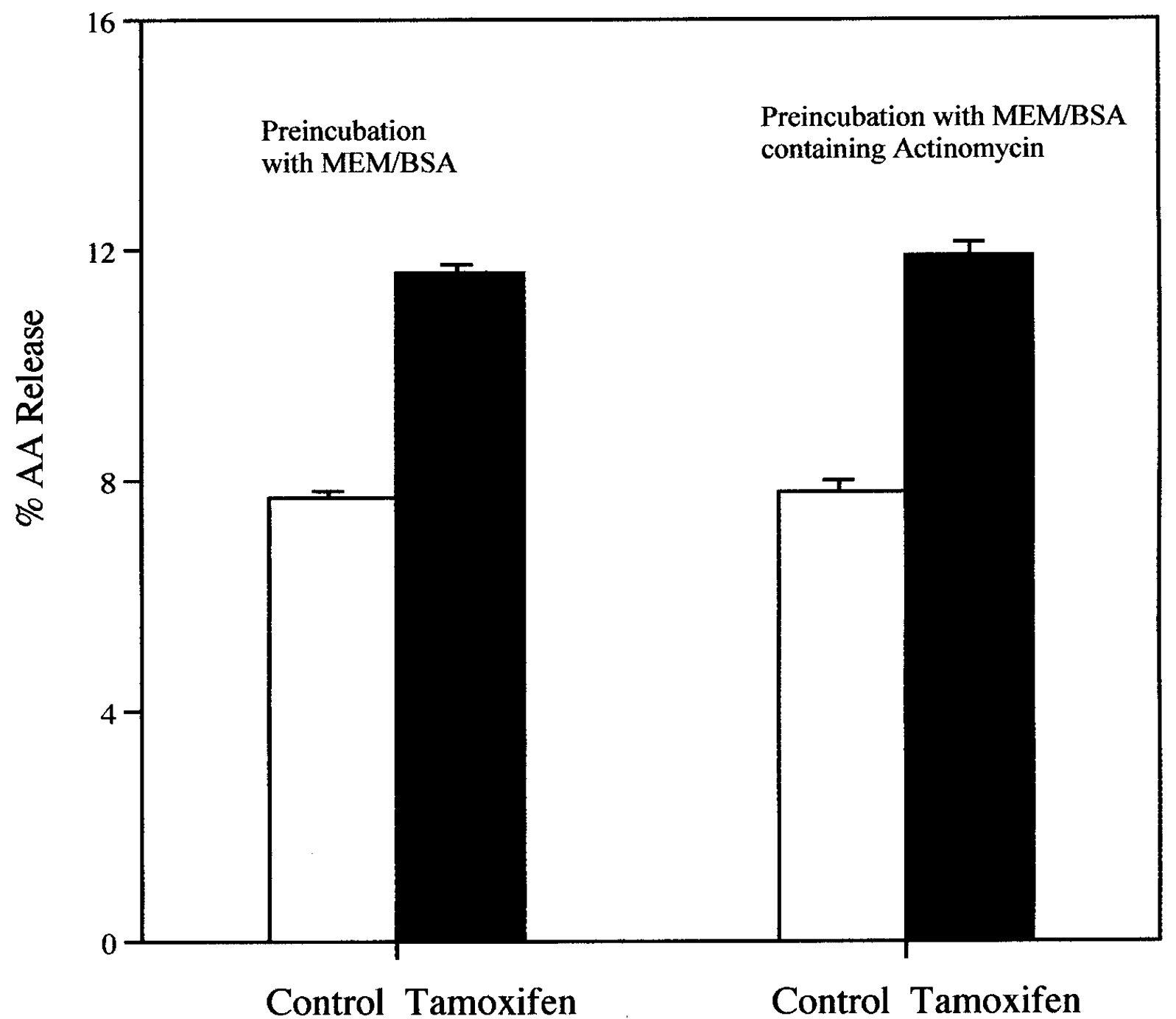

Figure 3

Effect of pre-incubation of cells with I $\mu \mathrm{M}$ actinomycin on the stimulation of AA release by tamoxifen. The cells were pre-incubated for 2-h in the presence of I $\mu \mathrm{M}$ actinomycin. During the 2-h pre-incubation, the \% AA released by incubation with the control MEM/BSA and MEM/BSA containing actinomycin was $4.2 \pm 0.2 \mathrm{I}$ (4) and $4.3 \pm 0.1 \mathrm{I}$ (4) respectively. Each bar gives the mean value and the brackets give the SEM. $(\square)=$ MEM/BSA; $(\square)=$ MEM/BSA containing $8 \mu M$ tamoxifen. The data recorded are the sum of the AA released during the 2-h pre-incubation plus the average of the subsequent 6-h incubation. They are representative of three separate experiments with similar results.

4). Tamoxifen at micromolar concentration may be intercalating into the lipid bilayer of the plasma membranes and affecting the fluidity and biochemical properties of the cell [21]. Another possibility is that tamoxifen is acting via $G$ protein-coupled receptors $[22,23]$.

\section{Conclusions}

Tamoxifen stimulates AA release from rat liver cells by a non-genomic, ER-independent pathway. In view of induction of apoptosis by AA, its release per se could, in addition to its effects on the ER, mediate cancer prevention. 


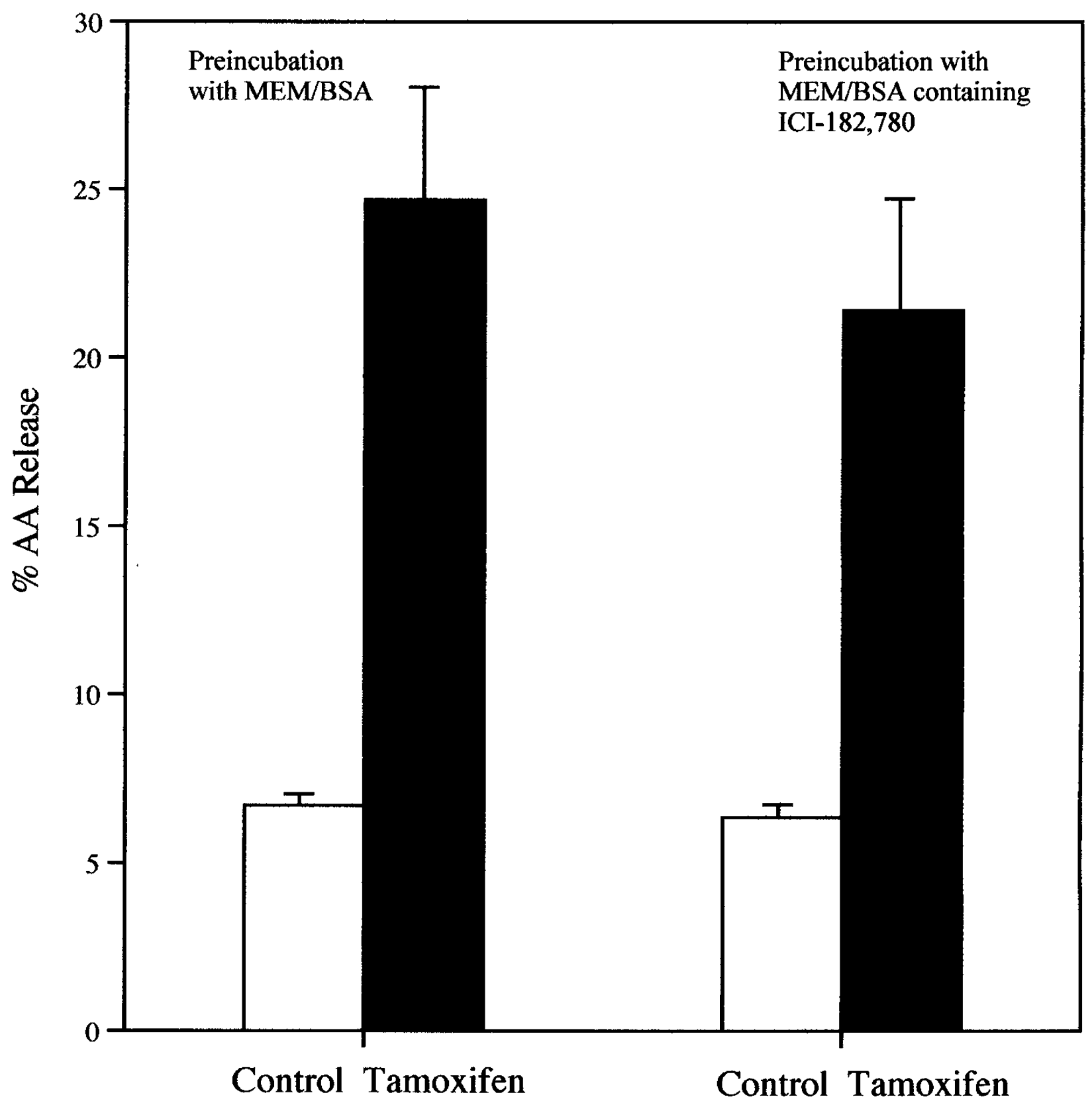

Figure 4

Effect of pre-incubation of cells with $50 \mu \mathrm{M}$ of estrogen antagonist ICI-I82,780 for 2-h on the stimulation of AA release by tamoxifen. The cells were pre-incubated for 2-h with $50 \mu \mathrm{M} \mathrm{ICl}-182,780$. The data recorded are the sum of the AA released during the 2-h pre-incubation plus the average of the subsequent 6-h incubation. During the 2-h pre-incubation, 3.I $\pm 0.02(4)$ and $2.6 \pm 0.26(4) \%$ AA was released by the control MEM/BSA and MEM/BSA containing ICl- $\mid 82,780$ respectively. $(\square)=\mathrm{MEM} /$ BSA $(\square)=$ MEM/BSA containing $16 \mu$ tamoxifen. Each bar gives the mean value and the brackets give the SEM. 


\section{Competing interests}

None declared.

\section{Acknowledgements}

I thank Dr. Armen Tashjian Jr., Department of Cancer Cell Biology, Harvard School of Public Health, for the continued interest in these studies and Hilda B. Gjika for preparation of the manuscript.

\section{References}

I. Jordan VC and Morrow M: Tamoxifen, raloxifene, and the prevention of breast cancer. Endocrin Rev 1999, 20:253-278.

2. MacGregor JI and Jordan VC: Basic guide to the mechanisms of antiestrogen action. Pharmacol Rev 1998, 50:15I-196.

3. Katzenellenbogen $B S$ and Katzenellenbogen JA: Defining the " $S$ " in SERMs. Science 2002, 295:2380-238I.

4. Gottardis MM and Jordan VC: Antitumor actions of keoxifene and tamoxifen in the $\mathrm{N}$-nitrosomethylurea-induced rat mammary carcinoma model. Cancer Res 1987, 47:4020-4024.

5. Levine $L$ : Does the release of arachidonic acid from cells play a role in cancer chemoprevention? FASEB Journal 2003, 17:800-802

6. Brash AR: Arachidonic acid as a bioactive molecule. J Clin Invest 200I, 107:1339-1345.

7. Surette ME, Fonteh AN, Bernatchez $\mathrm{C}$ and Chilton FH: Perturbations in the control of cellular arachidonic acid levels block cell growth and induce apoptosis in HL-60 cells. Carcinogenesis 1999, 20:757-763.

8. Chan TA, Morin PJ, Vogelstein B and Kinzler KW: Mechanisms underlying nonsteroidal antiinflammatory drug-mediated apoptosis. Proc Natl Acad Sci USA 1998, 95:68I-686.

9. Levine $L:$ Stimulated release of arachidonic acid from rat liver cells by celecoxib and indomethacin. Prostaglandins Leukot Essen Fatty Acids 200 I, 65:3I-35.

10. Levine L: Measurement of arachidonic acid metabolites by radioimmunoassay. Manual of Clinical Laboratory Immunology 3rd edition. Edited by: Rose NR, Friedman H, Fahey JL. Washington DC: American Society for Microbiology; 1986:685-69I.

II. Levine L: Nuclear receptor agonists stimulate release of arachidonic acid from rat liver cells. Prostaglandins Leukot Essent Fatty Acids 2002, 67:453-459.

12. Wakeling $A E$ : Use of pure antioestrogens to elucidate the mode of action of oestrogens. Biochem Pharmacol 1995, 49: I545- I 549.

13. Couldwell WT, Hinton DR, He S, Chen TC, Sebat I, Weiss MH and Law RE: Protein kinase C inhibitors induce apoptosis in human malignant glioma cell lines. FEBS Lett 1994, 345:43-46.

14. Dietze EC, Caldwell LE, Grupin SL, Mancini M and Seewaldt VL: Tamoxifen but not 4-hydroxytamoxifen initiate apoptosis in p53(-) normal human mammary epithelial cells by inducing mitochondrial depolarization. J Biol Chem 2000, 276:5384-5394.

15. Obrero M, Yu DV and Shapiro DJ: Estrogen receptor-dependent and estrogen receptor-independent pathways for tamoxifen and 4-hydroxytamoxifen-induced programmed cell death. J Biol Chem 2002, 277:45695-45703.

16. Levine L: Proteolysis negatively regulates agonist-stimulated arachidonic acid metabolism. Cell Signal 1998, 10:653-659.

17. Croxtall JD, Choudhury Q, White JO and Flower RJ: Tamoxifen inhibits the release of arachidonic acid stimulated by thapsigargin in estrogen receptor-negative $\mathbf{A 5 4 9}$ cells. Biochim Biophys Acta 1997, 1349:275-284.

18. Zhang W, Couldwell WT, Song H, Takano T, Lin JH and Nedergaard $M$ : Tamoxifen-induced enhancement of calcium signaling in glioma and MCF-7 breast cancer cells. Cancer Res 2000, 60:5395-5400.

19. Mandlekar S, Yu R, Tan TH and Kong AN: Activation of caspase3 and c-Jun NH2-terminal kinase-I signaling pathways in tamoxifen-induced apoptosis of human breast cancer cells. Cancer Res 2000, 60:5995-6000.

20. Peyrade F, Frenay M, Etienne MC, Ruch F, Guillemare C, Francois E, Namer M, Ferrero JM and Milano G: Age-related difference in tamoxifen disposition. Clin Pharmacol Ther 1996, 59:40 I-4I0.

21. Whiting KP, Restall CJ and Brain PF: Steroid hormone-induced effects on membrane fluidity and their roles in non-genomic mechanisms. Life Sciences 2000, 67:743-757.
22. Cato $A C B$, Nestl $A$ and Mink S: Rapid actions of steroid receptors in cellular signaling pathways. Sci STKE 2002. Reg

23. Hammes SR: The further redefining of steroid-mediated signaling. Proc Natl Acad Sci USA 2003, 100:2168-2170.

\section{Pre-publication history}

The pre-publication history for this paper can be accessed here:

http://www.biomedcentral.com/1471-2407/3/24/prepub

Publish with Bio Med Central and every scientist can read your work free of charge

"BioMed Central will be the most significant development for disseminating the results of biomedical research in our lifetime. "

Sir Paul Nurse, Cancer Research UK

Your research papers will be:

- available free of charge to the entire biomedical community

- peer reviewed and published immediately upon acceptance

- cited in PubMed and archived on PubMed Central

- yours - you keep the copyright
BioMedcentral 